\title{
The Silk Road as a Literary Spacetime
}

\begin{abstract}
It matters what matters we use to think other matters with; it matters what stories we tell to tell other stories with; it matters what knots knot knots, what thoughts think thoughts, what ties tie ties. It matters what stories make worlds, what worlds make stories.
\end{abstract}

- DONNA HARAWAY (2016)

In conversations among themselves, historians and archaeologists frequently repeat that "the Silk Road" is a made-up place. Of course, the mountain roads of the Caucasus and the Tian Shan, the crossings of the Black and Caspian Seas, the oases and caravan inns of Central Asia, and the markets of India and China all were "real"; we have archaeological and textual evidence of the people who traveled along these routes and dwelled in these places. Archaeologists have dug oases in the Tarim Basin, at Samarkand and in the Murghab Delta, uncovering material evidence for travel; meanwhile, historians have demonstrated the cultural transmissions between east and west in language, art, music, dance, food, and dress. Still, articles about the Silk Road will frequently begin with the same observation, that no one thought of a "Silk Road" until 1872, when the geographer Baron Ferdinand Freiherr von Richthoven wanted a metaphor to describe the connections of trade, especially but not exclusively in silken textiles, that tied Europe and the East together for almost two millennia. ${ }^{1} \mathrm{He}$ chose der Seidenstrasse, the Silken Road, and the metaphor stuck. A first reason for this is perhaps the sheer Orientalist romance of the term: how luxurious to walk the desert on roads of silk! A second reason, however, is the inherent power of metaphor as a literary device. The phrase the Silk Road prompts us to imagine the Eurasia of the past in a particular way, with very particular social dynamics, because it compels us as readers, listeners, and writers to insert ourselves in the knotty literary landscape that has been created around travel in Eurasia over the past twenty centuries. In particular, I am interested in the shape, the chronotopography (if Bakhtin will permit me), of some of the medieval accounts of travel, strange lands, and strange peoples and natures that make up part of what Robert Edwards called "medieval cosmopolitan 
imaginaries,"2 and which formed the foundations of ongoing practices of imagining medieval and modern Eurasia.

Medieval accounts of traveling, travelers, and foreign lands to the East play an important role in the reconstructed western history of literature, and of a particular modernist narrative about the progressive development of scientific thought. According to this narrative, part of what marked the transformation from antiquity or medieval-ity to modernity was a shift in the ways that people (primarily in Europe) described the world and made arguments about the "nature" of it. ${ }^{3}$ From a modern perspective, medieval accounts of travel and the world encountered through travel contain mutually incompatible forms of evidence: travelers valorized information both on the basis of empirical observation ("I saw this with my own eyes and thus it is true") and also on the basis of wonderment ("I have not seen this, but people tell me it happens and it is marvelous, so I write it down here"). Seeing an opposition between fact and marvel as two different and incompatible ways of understanding the world is supposed to be part of being a modern, scientific, as opposed to a medieval, superstitious person. ${ }^{4}$ To crib from Latour's argument about cultures of science, medieval accounts of marvels are framed as cultural "errors of identification," while modern science is successful objective observation of natural "truths."

A traditional position within the history of science is that as our culture has become more scientific, we have left wonderment behind-a consensus about scientists today is that they are supposed to argue things because they are observed facts, not because they are astounding marvels (though take a look through many publications and you will see a drive to do both, especially in archaeology). Literary historians argue, however, that there is a genealogical relationship between the following modern practices of writing worlds: travel writing, ethnography, archaeological accounts, natural histories, and speculative- or science-fiction stories. ${ }^{6}$ All of these forms of writing about encounters with other worlds-whether the world of the ancient past, of other cultures, or of other planets-have a "common ancestor" in the medieval travel narrative. Critically, however, genres like archaeology and ethnography are supposed to be solidly on one side of the science vs. wonder divide, while travel writing and science fiction are somewhere on the other. ${ }^{7}$ One key metaphorical technique that links these apparently disparate world-makings together is allegory, a complex symbolic labor by which characters, places, or events stand in for "real" things in the world-and a technique falsely used to characterize the exclusive epistemology of medieval or otherwise "premodern" peoples. ${ }^{8}$ Allegory, like all metaphor, is slippery, and depends on webs of cultural context that historians work hard to reconstruct. Critically, within hypothetically deterritorializing or decentering projects of world-making, allegory works to bring the subject back to the reader, to the reader's homeworld. You may know this technique from science fiction: writers like Le Guin, Vonnegut, and Atwood lean hard on allegorical fantasy as a critique of a mystified or naturalized 
reality. Allegory is also fundamental to the world-making of ethnography, both in the ways that practices or beliefs are read as "total social facts" and in the implicit or explicit invitation to reflect back from the foreign to the familiar. ${ }^{9}$ In medieval accounts of strange lands, creatures, and people, the reversal of wonder (i.e., the traveler's reflection of "but then what is normal to us would be wondrous to them") is part of an allegorical dialectic which recenters the reader even as their world expands.

There are interesting consequences to presuming a clean break between science and wonder, fact and imagination, matter and metaphor. One of them is a general presumption that part of what made the Dark Ages (a term most medievalists abhor) so "dark" was the fact that people learned about their world through indiscriminate combinations of empirical facts and marvelous fictions. A long-running trend in historical study of the Silk Road is therefore to try to weed out the facts from the fantasies, and to adjudicate which historical sources are the most "reliable" as accounts of the Silk Road world. ${ }^{10}$ I will start this book's exploration of historical accounts of the Silk Road with two assertions: First, that to presume that there was a real Silk Road that medieval writers were describing with greater or lesser accuracy is not always the most useful approach. Rather, and second, we need to approach the medieval Silk Road world as medieval people did, as a spacetime built in imaginations, perceptions, allegorical metaphors and wonderful dreams. This is not to argue that any given written account of medieval Eurasia is more important for understanding "what really happened" than the wealth of material evidence. Instead, what I am trying to unravel is the ways that material investigations of the Silk Road in the West have always already been shaped by the ways that that world (and the smaller worlds that made it up) was written about, read about, and imagined.

For instance, there are interesting patterns in the ways that medieval travelers wrote about the landscapes and creatures they encountered, patterns that crystalize into a topology, or structuring understanding, of the relationships between things in the world. When these topologies multiply across literary projects, they bloom into a topos, or a spatial trope, a tenacious influence on the way that writers create certain places and worlds so that their readers can find their way around. The first pattern is that a travel account with a first-person eyewitness narrator was a tropic way of organizing written descriptions of wonder as well as of fact. ${ }^{11}$ Part of the pleasure of experiencing a tale of wonder was linked to reading (or hearing) the embodied experience of someone encountering it, of being entranced, amazed, or terrified.

A second pattern is that, over the course of the Middle Ages, a topography of difference was drawn up in European imaginations. ${ }^{12}$ According to this prevailing cultural imaginary, marvels lived in the East. This was argued from two perspectives: first, that in the unexplored realms of the Orient there were more monsters, miracles, and marvels; and second, that what was "marvelous" to travelers from 
the West was quotidian for peoples dwelling in the East. ${ }^{13}$ These and other patterns became the warp threads of western ideas, not just about wonder, but also about the world, and the people, animals, and super/natural phenomena within it. These structuring tropes and patterns congealed over time into a chronotope, or spacetime, imagined in writing, reading, and telling, parts of which were only later given the name the Silk Road.

If we examine medieval travel narratives of what we call the Silk Road as literary spacetimes, as imagined worlds that medieval people lived within and which continue to shape our perceptions of Eurasian landscapes, then we must approach the combination of eye-witnessed evidence and wondrous half-truths and full legends which make up these accounts as a unified field of metaphorical world-building. What I mean here is, instead of the critical question being "which of these sources is the most accurate?" the question becomes "what kind of world is being written here? What are its topographies_of power, of danger, and of desire and delight?" Considered this way, the spacetime of the Silk Road emerges as a mechanism through which medieval people situated themselves within a world, rather than a description of a preexisting "reality." The historian Peter Jackson framed this mechanism as a way of making sense of human difference, which mediated the medieval European encounter with the Mongols and other peoples of the wider world, all of whom came into increasing contact in the High Middle Ages. ${ }^{14}$ Jackson drew on a system of literary cartography posited by Robert Bartlett for the thirteenth-century historian Gerald of Wales; Bartlett described the writing of commentators like Gerald as situating especially medieval European Christians at the center of concentric circles of familiarity and difference. The center circle of civilization was surrounded by a conceptual zone of barbarism: people who live in foreign, unorthodox, or more primitive ways. As Jackson described it, the third and furthest circle was "the abode of the marvelous, the alien, and the monstrous"; 15 a world with which, Jackson argued, Europeans had no direct contact before the thirteenth century. Within this framework, thirteenth century and later literary accounts of the worlds beyond the southern and eastern rims of the Mediterranean represent the labor of Europeans to pin newly encountered people and places within the marvelous and monstrous imagined landscape of that third ring. An effect of this was to make alien peoples and places comprehensible in cosmological terms, even if they were not made "familiar." Thinking about the Silk Road as a literary landscape also means that archaeologists can (and should) think about histories of the Silk Road in literary terms, as stories that have heroes and villains and, most importantly, which cohere in important ways as a genre and which do the work of literature in creating spaces and times-a written world of a peculiar shape.

Let's look briefly at a very few famous examples of medieval Silk Road travelers. First, I will introduce the Silk Road travel account as a kind of literature, a genre that has familiar, repeated structures, by looking at a handful of well-known 
accounts. Then I will narrow my examination to looking at how Armenia and the Caucasus in particular have been constructed as written worlds over the last two millennia. Ultimately my goal for this chapter is to show how certain forms of encounter with medieval Armenia and medieval Armenians-by travelers, historians, and archaeologists-have been themselves engagements with literary spacetimes. This examination is a necessary step in a critical archaeology of the Silk Road in Armenia, itself a storytelling of medieval life using texts, objects, buildings, and landscapes; I will explore the ways that historical sources, and analyses of material culture, and even reconstructions of landscapes have been framed within Silk Road spacetimes.

In addition to the myriad historical documents about life in various places in ancient and medieval Eurasia, from the Cairo Geniza to the thousands of records recovered from the Dunhuang caves, we also have numerous sources specifically about the road, about the experience of traveling from place to place along one branch or another of what would eventually be called the Silk Road. Looking at these road accounts as a body of literature is important to the task of thinking in critical terms about life on the Silk Road; taken in aggregate, accounts of travel between Europe and Asia have shaped the parameters for talking about that world. Working as a literary genre over the last few centuries, medieval and early modern narratives of travel became foundational to the ways we imagine distance and difference. Further, they established the literary dramatis personae for stories of the Silk Road-both the characters it was expected to meet, as well as the character of the protagonists (and villains) of the journey-as-story. The question of the stock characters of the Silk Road story is important when we consider the politics of medieval cosmopolitanism, and of reconstructing not just who was but who could be a protagonist in a Silk Road story.

\section{THE TRAVELER AS EMBODIED PROTAGONIST}

A first step in reconfiguring perspective on histories of the Silk Road is thinking of the narrators of Silk Road travel tales as literary protagonists, as personalities who shape and are shaped by the events they describe. This means, on the one hand, thinking critically about the embodied perspectives of travelers, situating narrative description within the moving, seeing, tasting, and remembering body of a traveler. On the other hand, this requires that we think about the performance of traveler-as-persona, and especially of how the writers of travel accounts and geographies in the medieval period wrote their personae as endowed with particular forms of embodied expertise, authority, and integrity-all of which added veracity and authority to their written world. A fantastic and early example of this literary performance appears in the Best Divisions for Knowledge of the Regions, a geography written in the tenth century by the Arab scholar al-Muqaddasi. In this work, al-Muqaddasi set out to fill what he saw as a critical gap in knowledge of the 
world: the roads, stopping places, and character of cities which tied the lands of the caliphate together into an intelligible social whole. ${ }^{16}$ In the Divisions al-Muqaddasi described not only cities and their inhabitants, but also infrastructure, customs, and even archaeological ruins. Critical to my purpose, al-Muqaddasi also presents a perfect example of the development of the travel writer who is an authority on his subject due to the experience of traveling, and therefore to a kind of worldly knowledge and experience that is contained within the exceptional mobile body of the traveler. Al-Muqaddasi parallels the knowledge compiled and contained in the written text with the experience collected within his authoritative, singular self. Read how al-Muqaddasi boasts of the breadth of his experience on the road, basically laying out his resume as a trustworthy source:

Besides, I have had my share in all that commonly falls to the lot of travelers, with the exception of begging and the commission of a grievous sin. I have attended lectures in law and ethics; practiced asceticism and devotion, lectured, in my turn on law and ethics; preached from pulpits; cried the hour of prayer from minarets; officiated as Imam in masjids; delivered public discourses . . . frequented schools; pronounced special prayers in assemblies; spoke in meetings; swallowed harisah with Sufis, tharid with the monastics, and aşidah with seamen. ${ }^{17}$ I was driven in the night from mosques; have wandered in solitudes and lost my way in the deserts; was, for a time, earnestly bent on devotion; and have, at other times, openly acquired ill-gotten wealth. I have associated with the devotees of the mountain of Lubnan; mixed with persons in authority for some time; owned slaves; and carried things on my head in baskets. I was very near drowning on several occasions, and have, a number of times, been plundered in predatory attacks on our caravans. ... I have been confined in prisons and arrested as a spy; have witnessed the fighting of ar-Rum in vessels of war and the striking of bells in the night; have bound books for hire; paid for water with my songs; traveled in litters and on horseback; walked through hot winds and snows; lodged in the precincts of royal courts among noblemen and lived in the midst of ignorant persons in the weavers quarters. ${ }^{18}$

Consider the breadth of experiences covered in this excerpt, as well as the span of distance and the variety of spacetimes: nights and early mornings, tops of minarets, decks of ships, dangerous roads and holy places, rough seas and deserts. Each phrase is a small story, the intimation of a gripping tale-or perhaps a story of edifying tedium-that al-Muqaddasi could tell. Especially remarkable in this passage are the points of inflection, when al-Muqaddasi shifts from relating his credentials as a respected man of piety, to recounting the variety of his experiences on the road. This demonstrates al-Muqaddasi as a very particular kind of able traveler, who is apparently equally at home doing manual labor and owning laboring people, working a trade and stealing. Of particular significance for the latter parts of this book are al-Muqaddasiss invocations of foodstuffs in order to mark social difference. He demonstrates his ability to be "at home" with a variety of peoples by describing sharing their meals: harisah, the favored humble meal of 
Sufi brothers, ${ }^{19}$ tharid, the festival broth of devout Muslims, and aşidah, the meal of simple sailors. His appreciation of this diverse-but also devout-menu frames al-Muqaddasi as the consummate cosmopolitan in the sense discussed in the last chapter. He is a citizen of the world, at home everywhere, and specifically comfortable in the attitudes and comforts of a body that labors, that experiences heat and cold, that hungers for both humble and elegant dishes. The rest of his geography, then, is backed up by the authority of this cosmopolitan, embodied subject to faithfully report on the nature of the world in all its wonder.

Next I want to look at two European travel accounts from the thirteenth through fourteenth centuries, at the height of the Mongol era. Marco Polo and the author known as John de Mandeville wrote equally influential accounts of travels from Europe to the Mongol court and beyond. Marco Polo is the more famous of the two, in part because his story is thought to be more factual and accurate. ${ }^{20}$ As discussed above, my interest in introducing these two geographies is not to compare which one of them more correctly describes the "real" world of the medieval Silk Road; rather, I want to think about some of the mechanics through which Marco Polo and John de Mandeville constructed that world through the writing of their historically influential accounts.

Marco Polo's Travels, also known as the Description of the World, is, most basically, an account of the lands of the East by a Venetian merchant traveling to the court of Kublai Khan and onward to China and Southeast Asia in the later decades of the thirteenth century. Debate surrounding Marco Polo as a historical figure and author abounds, but there is general agreement that the Travels was coauthored with a romance storyteller, Rustichello of Pisa. The Travels is a motley collection of literary references, tropes, and mirabilia, as well as "factual" events and phenomena that Polo claims to have witnessed himself. The prologue casts the work as a romance, the travels of a youth to a faraway land where he finds his fortune and then voyages across land and sea with a beautiful and exotic princess, Kököchin. But the greater part of the Travels is a listing of marvelous lands, peoples, creatures, things, and events. Armenia plays a significant role in the Travels, implicated in the opening declaration of the truthfulness of the subsequent narrative: "it is true that there are two Armenias"-a declaration which is paired and also contrasted with the declarative mode of the rest of the book: "and yet I tell you. ${ }^{"{ }^{21}}$ The formulaic-ness of these and other declarations which punctuate the text- "let me tell you ... and what more can I tell you of it? ... And why am I telling you of this at such length?" - suggest the status of the Travels not as a scientific report but as a romance, similar to the Arthurian sagas of travel, sudden misfortune, and grace regained, of which Rustichello was a practiced and popular author. ${ }^{22}$

Why does it matter whether Marco Polo's account was one kind of writing or another? The literary historian John Larner extensively reviews the debates surrounding the text of the Travels, the character of Polo's authorship, and, critically, the categorization of the book as a work of literature. According to Larner, 
a recurring theme within these debates is the opposition between Polo as a reliable eyewitness who really saw the things he described, and the romantic liberties taken by Rustichello of Pisa in order to produce a palatable account for western readers. But who is the true author of the tales of the Travels? Where do Marco Polo's facts leave off and Rustichello's fantasy begin? Larner cogently argues that such questions essentially bark up the wrong tree,${ }^{23}$ and that ultimately what matters for the history of knowledge of the east in the west is not the identities of the authors, but the influential book itself and the form it takes. To ask these questions about texts like the Travels, then, is to ask what kind of written world they were. ${ }^{24}$ What kind of spacetime? If the Travels fit into known genres, then was it familiar to its readers and listeners as a spacetime within which actions took place, lessons were learned or unlearned, and fortunes won and lost? To look archaeologically at works like Marco Polo's Travels means thinking about them as crafted things, and also as spaces constructed from metaphor and trope, from the time and distance of narrative action. As archaeologists we are interested in the literary genre question insofar as it helps us understand Marco Polo's (and Rustichello's) writing as a built space in which to think, act, and live. From this perspective, then, it matters that the literary space of Silk Road travel is closely related to the literary spaces of courtly romance, eastern adventure, and perhaps even Chinese courtly performance. ${ }^{25}$ It also matters more what actual shape that world takes-and on this point as well, John Larner made a fantastic observation specifically related to the "route" of Marco Polo across Eurasia. Much of the Travels is written as an itinerary, with different sections opening as if describing the movement of a traveler from one place to the next, following the movement of a reader between paragraphs: "The traveller who leaves this city [Yazd] to proceed further [east] rides for seven days over a plain." "When the traveller leaves this city [Chagan-nor] and travels north-northeast for three days, he comes to a city called Shang-tu." 27 "After leaving the river [Brius] the traveller continues westwards for five days, through a country with numerous cities and towns which breeds excellent horses." ${ }^{28}$

This itinerary carries readers west to east and back again, traveling through the world of the book, even though they are not frequently reminded of the travels of Marco Polo's own body. Larner argues that this linear itinerary ${ }^{29}$-reproduced in countless maps by ambitious historians over the last few centuries-does not represent the actual path traveled by Marco Polo. Rather, the linear description is as it appears: a narrative frame, a device for storytelling, an organizational scheme for otherwise disjointed observations drawn from the genres of travel and adventure. As Larner later writes, "There is no description here of the route of the Polos through Asia; the route is just the means by which Marco and Rustichello lead their readers from West to East and then back from East to West, the route of the narrator through his book." ${ }^{30}$ The ultimate outcome of the narrative and metaphorical forms deployed in the Travels, according to Larner, is the production of a singular, coherent space within its pages: " the cumulative effect ... would have been 
to give the medieval reader an extraordinary vision of a whole hitherto unknown world of cities engaged in trade and commerce set within the east." 31 The spacetime of this wonderful world, traversed along a linear itinerary in the mind of the reader, is a critical legacy of the Travels - it is the spacetime we step into when we set ourselves the task of imagining the medieval Silk Road. The spacetime of the Travels is particular to its protagonist: a capable, persuasive, and male traveler who is on an adventure. Marco Polo always arrives on time, always escapes-until of course, the arrest and imprisonment which provide both the beginning and end of his story. To say that Marco Polo's itinerary is a fiction is not to cast it aside in favor of better, more accurate histories-rather, let us continue our examination of other fabrications of Silk Road travel, other created landscapes of Eurasia. These created or imagined spacetimes continue to shape the topography of thought about the Silk Road and about places along it, like Armenia, and about the world of the Middle Ages.

In the introduction to his nineteenth-century translation of The Book of Marvels and Travels, by John de Mandeville, Malcolm Letts is compelled to comment on the genre of the work he has transcribed: "the book sets out to be a guide to the Holy Land, but it soon becomes apparent that its main purpose is not to guide or instruct, but to entertain." 32 The account left by an author calling himself John de Mandeville, composed around 1360, tells of travels to the east; however, the scholarly consensus is that Mandeville's tale is not an eyewitness account but a compilation of wondrous tales of the Orient drawn from various sources. Other than the Travels of Marco Polo itself, accounts freely plagiarized by Mandeville include the descriptions of John de Plano Carpini, who traveled through Armenia to the court of the Mongol khan in 1245, and whose journey was then described in Vincent de Beauvais' 1264 Speculum mundi. Mandeville also drew on the published account of Het'um, the Cilician Armenian king mentioned in the previous chapter, and on the account of William of Rubruck, both of whom traveled across the Caucasus as emissaries to the Mongol court. ${ }^{33}$

Mandeville baffled modern geographical historians like Letts with an apparently irreconcilable combination of facts and marvels. ${ }^{34}$ The Book of Marvels interweaves routine travel itinerary and geographic descriptions with tales of transformation, miracles, and of the Christian king in the east, Prester John. ${ }^{35}$ For instance, if we go looking for an eyewitness account of fourteenth-century Armenia within the Travels, we must reconcile John de Mandeville's straightforward account of Armenia as a kingdom west of Persia that "was sometime divided into four kingdoms" with Mandeville's description, a few paragraphs later, of a "truly marvellous" region in Abcasia: "and this region is entirely covered in darkness so that it has no light by which one can see, and nobody dare go into this region because of the darkness. Nevertheless, people from near that region say they can sometimes hear men talking, horses whinnying, and cocks crowing, and they know well that people are living there, but they don't know what kind of people." ${ }^{36}$ 
This description is not only evocative, but it has a literary pedigree as well. Already by the Middle Ages the tale of a land of darkness had a long lineage; centuries before, Herodotus cited a dark land in the realm of the Scythians where the Amazons would meet their lovers. The dark land featured in the Alexander Romance of the early Middle Ages, a text that generated topoi which circulated widely through Eurasia, inspiring episodes in travel accounts like that of Ibn Battuta, and scenes in epics such as the tenth- or eleventh-century Shahnameh (Book of Kings) of Firdowsi, which in turn influenced numerous accounts such as the early fourteenth-century Compendium of Chronicles, by Rashid al-Din.

Mandeville conveyed a maplike understanding of places known to us to be "real," and commented on the spherical form of the earth, and yet described impossible wonders clearly drawn from literature-therefore constituting an aporia in the history of scientific thinking. According to the mid-twentieth-century editors of Mandeville, the passage of time and the ultimate triumph of science relegated Mandeville's account to "the shelf with the Arabian Nights Entertainments and the fairy tales." 37 Paul Smethurst takes a revisionist approach to the genre of Mandeville's Travels, arguing that the frustration that the Travels spurs in modern audiences - the questions of whether it is trying to be accurate, trying to entertain, or even whether it is openly plagiaristic or deceptive-indicates not the failure of Mandeville's account as science but, rather, the inadequacy of our modern categories. Reflecting on the willful inconsistencies of the account, Smethurst argues that Mandeville's Travels is instead a postmodern text ${ }^{38}$ - that is, an effective rejection of the schemas of knowledge and ordering power sustained by categorization such as fiction/nonfiction, science/fantasy.

Smethurst's interpretation of The Travels opens another question: how can a medieval (premodern) text be postmodern? In a generous and literary reading of Mandevilles Book, Karma Lochrie defines it as a cosmopolitan utopia which decentered the west. ${ }^{39}$ My own reading calls into question the opposition between medieval and modern ways of writing the world, and especially the opposition between allegorical and empirical ways of knowing. Soon after leaving India, Mandeville digresses in a discussion of the shape of the earth and the possibility of circumnavigation. He tells an anecdote of a man who "went so far in his travels by land and by sea that he found an island where he heard people speaking his own language." ${ }^{40}$ Mistaking his own country for the most foreign land of all, the man turns around and takes the long way home. This section is delightfully polysemous; even as Mandeville demonstrates his "modernity" by moving from a circular to a spherical map of the world, he resolutely deploys that map as a metaphor for the ways that a traveler, encountering strange or monstrous others, reflects on (returns to) his own home-world. Others are revealed to be selves; science does the work of allegory.

So, instead of asking how modern these texts were, we might ask: What did they make? What kinds of written worlds, what sorts of apparatuses, are these? 
What are their topographies of power and possibility? Mandeville's account is a marvelous world, which, like later cabinets of curiosity, served to create an authoritative account of wondrous places, people, and occurrences, and as a book, could itself circulate and delight. ${ }^{41}$ Just as a cabinet of curiosity is not just a box of things, the travel account is different from a natural history in that the wonders in it are integrated by the eyewitness, and its spacetime is unified by the mobile subject of the traveling narrator. Like Marco Polo and Rustichello's Travels, and like al-Muqaddasîs Divisions, Mandeville's world is organized as a journey, with each landscape and wonder within it encountered by a mobile traveling subject. In contemporary accounts, where the personality and the body of the subject are brought more to the fore, this motif of encounter (surprising, terrifying, confusing, delightful) is underscored as a way of drawing the reader into a shared sense of the wonder of the Silk Road.

\section{The Encountering Body}

The sensation of encounter, both with strangers and with the limits of one's own known and familiar world, are clearly present in the travel account of Ibn Battuta, one of the most famous travelers from this period. Ibn Battuta's Rihla is full of startling encounters with difference-especially in Eastern Anatolia and the Caucasus, where Ibn Battuta travels between Christian, Muslim, and Mongol worlds. In a parallel to Marco Polo's Travels, Ibn Battuta is tasked with escorting the pregnant Khatun Bayalun, a young wife of Sultan Uzbeg, the khan of the Golden Horde, on a journey to visit her Christian family in Constantinople, where she plans to give birth to her first child. The repetition of this structure, beyond stressing the constrained ways that women could be imagined as mobile in the Middle Ages, further demonstrates the reliance of Silk Road travel narratives on the tropic forms of medieval romance. As I have mentioned, gendered bodies are not incidental characters in Silk Road stories. One of the effects of figures like Kököchin (the princess in the Travels) or Khatun Bayalun is to provide an alluring and intimately approachable embodiment for the otherness of the cultures encountered by the protagonist-indeed a body that is literally under his control and care. ${ }^{42}$ The exotic bodies of these princesses, in their foreign compliance, illustrate the agentive subjecthood and relative structural freedom of Silk Road protagonists, those who travel and tell their own stories.

In Ibn Battuta's account, however, Khatun Bayalun demonstrates the role of bodily comportment in the performance of political and spatial agency. Ibn Battuta describes the process by which Bayalun tracks the distance traveled from her husband's ordu through transformations of her bodily and everyday practice. Moving westward, she leaves behind her portable (tent) mosque and resumes bodily habits of her own culture, drinking wine and eating pork. ${ }^{43}$ This episode demonstrates both the necessity of thinking about bodies and their appearance when we think about medieval travel, and also the significance of women-as brides, mothers, 
daughters, and patrons in their own right_-in knitting together disparate cultures in the Middle Ages. Having escorted the Khatun to her home city of Constantinople, Ibn Battuta recounts yet another moment of embodied encounter, of confrontation but also of inversion, which hinges upon his own mobile body. Until his arrival in the Christian city, the mode of the narrative has been that of following Ibn Battuta's traveling self as he encounters marvels scattered in the world, including meteors, lands of darkness, and strange customs and foods. We are reminded of al-Muqaddasī, as in Constantinople Ibn Battuta's body itself becomes the marvel. The traveler recounts his (possibly invented) encounter with the old king Jirjis, a devout Christian described as wearing a hair shirt. Upon hearing that in his travels Ibn Battuta has been to Jerusalem, the king reacts with wonder:

The king asked about me, then stopped and said to the Greek [Ibn Battuta's companion, denoted using the general term for a Christian] who knew the Arabic tongue: "Say to this Saracen ... 'I clasp the hand that has entered Jerusalem and the foot that has walked within the Dome of the Rock and the great church called Qumamah, and Bethlehem." And so saying he put his hand upon my feet and passed it over his face. I was amazed at their belief in the merits of one who, though not of their religion, had entered these places. ${ }^{44}$

In this moment Ibn Battuta's body is itself a marvelous object, capable of transmitting grace through its contact with holy places. Thinking back to the example of the Hereford mappa mundi, Ibn Battuta's body in this episode works in the same indexical mode. The king is able to "touch" the holy sites of Jerusalem through the powers of extension possessed by a mobile body. This moment in Ibn Battuta's account demonstrates another critical aspect of the Silk Road as a literary place. Travelers in literary accounts of the Silk Road are on adventures, and like other literary adventurers they are changed by their encounters. The case of Ibn Battuta shows that by the fourteenth century the idea of an encounter that shapes the self was not so much western as globally "modern." This close link between the exquisite experience of travel (which can be described) and the production of an exquisite self through traveling (which is unique, and authorizes the travel narrative) carries over from the medieval period into modern ways of thinking the mobile, cosmopolitan self, and of thinking literary landscapes like the Silk Road that exist to transform the traveler.

\section{HOW TO BE A SILK ROAD PLACE: MEDIEVAL ARMENIA AS FAMILIAR AND FARAWAY}

The discussion of literary landscape in this chapter has brought us to the point at which, when we describe a place as "along the Silk Road," we understand that historical imagination of such places is necessarily shaped by the literary topographies of Silk Road stories. How, then, have these stories shaped historical encounters 
with Armenia? How was Armenia, a mountainous place between Europe and Asia, constructed as a literary landscape by medieval travelers? I want to start here, constructing the view of Armenia from the road-or, rather, from a road-shaped literary imaginary-so that I can depict the Armenia of travelers' accounts as a place with familiar landmarks and topographies. Again, neither of these Armenias is more "real" than the other: they both had and have material ramifications for people living in Armenia and outside it. But my overall project with this book is to explore the multiple imagined worlds-literary and material-which intersected in the lives of people in Armenia in the medieval period. A first step is looking closely at how Armenia and Armenians were encountered in writing, and constructed as characters within the literary landscape that the western tradition imagines as the Silk Road.

So when we ask what kind of place Armenia was in the thirteenth through fifteenth centuries we need to look in the shared spacetime between written and material worlds, where medieval people dwelled, constructing and inhabiting intersecting bodily, spatial, and cosmological worlds. ${ }^{45}$ As I move from classical and medieval travel accounts to narratives from later centuries and then up to the recent past, I will draw attention to the construction of Armenia, not only in place, but in time as well. As discussed earlier in this chapter, the Silk Road is a central concept used for imagining our place, not just in a spatial world, but within a linear timeline. A fascinating tendency in travel narratives is for the peoples and places of the Silk Road passed by a traveler to map onto the passage of time, between "long ago" and now, between a "dark ages" and a civilized modernity, or between a time of credulous allegory and modern science.

In considering the layered literary-historical construction of the Caucasus, I must briefly sojourn even further back in time than the Middle Ages, to the landscapes of Greek (mis)adventure. Xenophon's late fifth-century b.c. Anabasis is the narrative of an army of Greek mercenaries stuck in Persia after a sudden shift in the landscape of war. Their journey to reach the Black Sea coast is a Romantic saga, as the Greeks pass through mountain valleys inhabited by sometimes friendly, sometimes hostile, but always unsettling mountain-dwelling natives such as the Carduchians. Xenophon describes their entry into the Caucasus: "Thus the Greeks bivouacked for that night in the villages, while the Carduchians kindled many fires round about upon the mountains and kept shouting to one another." 46 The Carduchians, unlike the Greeks, are very much in their element in the mountains, and in fact appear as elemental to the mountains in Xenophon's account, an affective melding of humans and geology that seems to be one of the lasting legacies of the Anabasis. This short excerpt also suggests the complexity of the Caucasus landscape, which is not only visually prepossessing, but also delineated in strange and frightening sound. A climax of sorts occurs when the Greeks, nearly out of supplies, must pass through a territory populated by mountaintop fortresses, and made impassable by the local people hurling boulders down from their forts 
and crushing the Greek soldiers. ${ }^{47}$ The Greeks besiege a fort until the inhabitants run out of stones to throw-only to be horror-stricken at the sight of the mountain people throwing themselves and their children off the battlements instead, in an uncompromising, insensate human rockfall. But Xenophon also observed the peoples of the Caucasus in their own context, describing their particular way of living: "The houses here were underground, with a mouth like that of a well, but spacious below; and while entrances were tunneled down for the beasts of burden, the human inhabitants descended by a ladder. In the houses were goats, sheep, cattle, fowls, and their young; and all the animals were reared and took their fodder there in the houses." ${ }^{48}$ In the context of the Anabasis this description serves to further root the peoples of the Caucasus within their landscape: humans and animals dwelling together within a stony earth, all reduced to the status of wild nature.

Travel accounts from the thirteenth and fourteenth centuries (and medieval histories like that of Kirakos Ganjakec'i or Step'anos Orbelyan) show that in this period Armenia and the Caucasus were dynamic landscapes through which people were constantly mobile in the undertaking of projects of politics and social life-and these projects in turn were integral to maintaining an imaginable, operable world within which all these people were acting. But here I will move from discussing the practice and politics of writing/making worlds to the cosmopolitanism of acting, of getting things done, within these made worlds. Counter to Romantic notions of globalized "nonplace," just because the world was connected doesn't mean it was seamless or coherent for the people moving through it, even those who were hypothetically skilled at writing and acting. ${ }^{49}$ Cosmopolitanism was (and is) messy, and sometimes painful. ${ }^{50}$

The high medieval travel account of Friar William of Rubruck is contained within a letter addressed to his patron, King Louis IX of France. As described in the last chapter, the appearance of the Mongols at the eastern edge of European Christian awareness of the world spurred wonder and hope that the Mongols might be enticed to side with Christendom in the apocalyptic conflicts of the crusade wars. Rubruck was one of a series of Franciscan friars dispatched on missions to the khans, seeking political alliance and the symbolic conversion of the Mongols. Rubruck himself traveled a winding route through the Caucasus and over the steppe to the court of Möngke Khan at Karakorum, the capital of the Mongol world in the mid-thirteenth century. As Rubruck moves farther north, away from lands where he feels more "at home" - for instance, like the cities of Erzinjan and Ani in Armenia-his narrative is marked by discomfort, displeasure, and disgust. Traveling among Mongols, sharing their food, and observing their customs, Rubruck writes a litany of complaints back to his patron: about the cold, dirt, manners, and of course the food and drink. He only slowly learns to enjoy kumiss, the fermented mare's milk drunk with relish by the Mongols, and is generally overwhelmed (or at least his account is) by experiences of cultural mistranslation and alienation. ${ }^{51}$ His 
complaints make Rubruck a reluctant cosmopolitan. He struggles to work outside of the cultural frameworks in which he is situated, and for that reason his mission to "convert" Möngke Khan is in many ways an embarrassing failure, and also a demonstration of the real ways that medieval human subjects were themselves structured by worlds even as they wrote them.

In 1255, on his return journey along the Caspian shore and through the Caucasus, Rubruck was hosted by an Armenian prince whom he calls Sahensa. This prince was almost certainly Šahnšah, ${ }^{52}$ the son of Zak'are Zak'aryan, an Armenian-Georgian general who was instrumental in the Georgian Bagratid seizure of territories in central Armenia from the Seljuks in the late twelfth century. ${ }^{53}$ Resting at the home of Šahnšah in the city of Ani, Rubruck recounts: "It was his father, named Zacharias, who acquired this territory, plucking its Armenian population out of the Saracen's grasp.... I took food with Sahensa, and was shown considerable respect by him, his wife, and his son, Zacharias, a fine looking and sensible youth who asked me whether you [King Louis IX] would be willing to retain him if he joined you." ${ }^{34}$ This episode shows us several things. First, it foreshadows the (disastrous) uprising of the "sensible youth" Zacharias Zak'aryan against the Mongols a few years later. Second and more interestingly, this description effectively casts the Armenians-princes of large cities, embroiled in complex politics of their own-as accessory characters in William of Rubruck's own journey. Šahnšah and his family appear in this narrative because they are hospitable to Rubruck, and potentially supportive of his patron's political interests. Ultimately two things are downplayed in Rubruck's account: both the political world that he passes through in Armenia (and which continues after he leaves), as well as the importance of hospitality in places like Armenia in producing a coherent world for travelers in the thirteenth century to move within.

I want to conclude this chapter by looking at the ways that classical and medieval techniques of writing about travel and about Armenia have carried through subsequent periods. This is an important question, as layered medieval and early modern accounts of this region continue to shape the imaginaries of novelists, directors, travelers, and bureaucrats, as well as historians and archaeologists.

In the early modern period (sixteenth to eighteenth centuries), overland routes through Armenia as well as developing maritime routes formed the basis for a globalism produced by traveling people, who maintained and enhanced the taste for and access to foreign goods through their descriptions of foreign places. ${ }^{55}$ The overland routes from India to Persia and through the Caucasus and Anatolia during this period were maintained largely by networks of Armenians centered at New Julfa, Isfahan. This suburb of consummate merchants was described by a number of European travelers during this period, including the Russian Fedot Kotov, ${ }^{56}$ the Frenchmen Jean Baptiste Tavernier and Jean Chardin, ${ }^{57}$ and the British emissary Sir Thomas Herbert, ${ }^{58}$ all of whom (among many others) traveled during the reign of the Safavid Shah Abbas I and his successors, in the seventeenth 


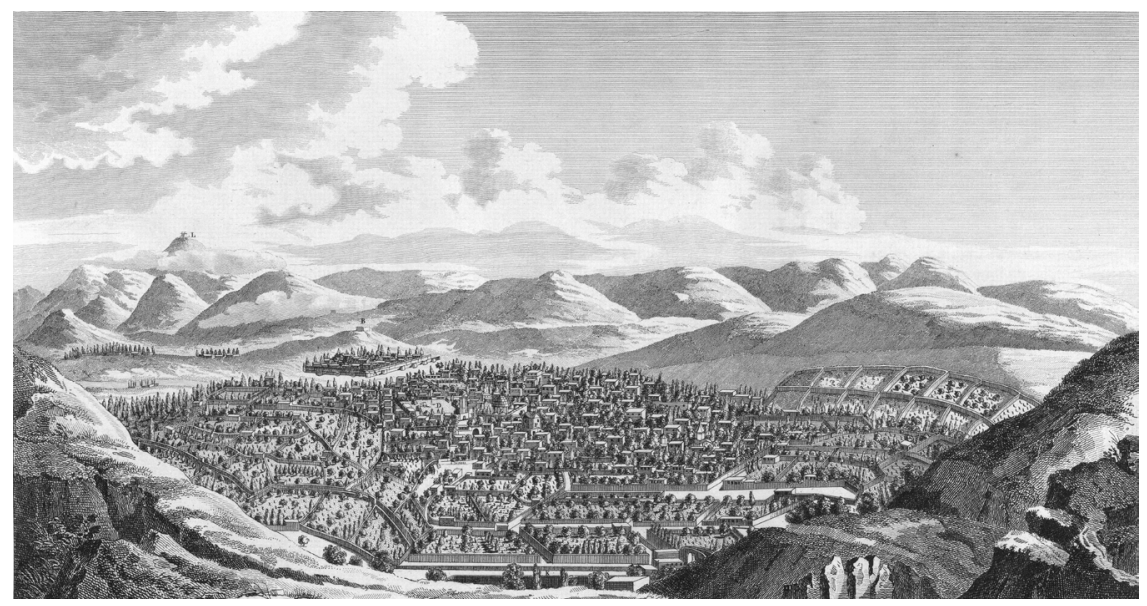

FIGURE 2. A detail from Jean Chardin's 1672 engraving of Yerevan. Note the inclusion of a tiny Noah's Ark atop Ararat in the background on the left. WikiCommons Open License.

century. Many of these travelers took a route south from the ports of the Black Sea, passing through the Caucasus on their way to Persia. We have illustrations from the 1670 os by both Chardin and Tavernier of Yerevan and surrounding sites. Both of these early modern accounts are remarkable for their acute awareness that Armenia is the land of an ancient Christianity: they are much more interested in the religious significance of the Ararat plain than they are in the people currently living there. Both visit the holy see at Ejmiatsin, and Tavernier travels to the semi-subterranean monastery at Kickart (Gełard, built in the tenth century), where he was shown various relics including a lancehead understood to be that of Longinus, the Roman soldier who pierced the side of Christ. Taviernier included an engraving of the spear (which object is still on display today along with other relics at Ejmiatsin) to reiterate the verity of his eyewitness account. An effect of the writings of these early modern travelers is the construction of Armenia as a collapsed spacetime: there is a simultaneity to biblical events and the lives of people living in the Ararat plain. This simultaneity is effectively demonstrated by Chardin's engraving of Yerevan, as viewed perhaps from a vantage point on the western slopes of the Gegham mountains (see fig. 2). Chardin's illustrator presents us with the buildings and gardens of Yerevan and surrounding mountains-and includes Noah's ark perched atop Ararat, peeking above the clouds on the horizon.

Tavernier notes that Yerevan "lies in a most plentiful country of all things necessary for human life, but especially abounding in good wine. It is one of the best provinces of Persia, and yields the King (Shah Abbas I) a very large revenue, as well as by reason of the goodness of the soil, as for being the great thoroughfare of the caravans. ${ }^{\prime 59}$ Indeed, Tavernier's experience of Armenia was no doubt enriched by the fact that he was traveling in a band of Armenian merchants, who were agentive 
in perpetuating networks of travel even while operating under Safavid hegemony. ${ }^{60}$ It was almost certainly these anonymous Armenians who told Tavernier the names of active medieval monasteries like Gełard, as well the names of places like Ani and Artashat, the then-ruined capitals of medieval and classical Armenia.

\section{Imperial Imaginaries}

During the eighteenth century, the southward expansion of the Russian Empire resulted in a boom in scholarly and literary imaginaries of the Caucasus and its peoples. In this period production of knowledge about the Caucasus was transformed into an explicitly imperial project, situating Russian power as both authoritative and inevitable within the history of the region. The labors of explorers, scientists, and travelers constructed the Caucasus in this period as an object of imperial interest and control, specifically through the writings of a series of research expeditions in the second half of the eighteenth and the early years of the nineteenth century. These expeditions were ordered by Catherine the Great in the service of better imperial understanding of peoples living beyond the pale of Russian civilization. According to historian Charles King, the mission statements of some of these fact-finding expeditions, such as the 1807 mission of Julius Klaproth, took a distinctly literary tone: "The academy was highly specific about the kinds of things on which Klaproth was expected to report. Are there traditions respecting the existence of Amazons? Who are the likely descendants of the Scythians, the ancient steppe dwellers described by Herodotus?" ${ }^{11}$ The Russian expeditions which would produce authoritative accounts about the Caucasus and Caucasians thus set out with expectations for what (and whom) they would find in that landscape extracted from wondrous classical and medieval spacetimes. I can imagine the members of Klaproth's party enquiring about Amazons in Tbilisi with the same earnest tone in which William of Rubruck asked priests at the court of Möngke Khan about the nearby existence of monsters such as blemmyes and cynocephali described in the writings of Isidore of Seville. ${ }^{62}$

Over the course of the next century, the landscapes of the Caucasus would be further explored and explicitly rewritten, transformed into literary landscapes for the habitation of imperial Russian imagination and yearning. The early nineteenth-century entrance of Russian imperial troops, scientists, and explorers into the Caucasus coincided with the blooming of Russian (and European and American) Romanticism and its component Orientalism. ${ }^{63}$ The Russian literary obsession with the Caucasus is an enormous topic; for the purposes of this book it is interesting to note Susan Layton's critical point that poets and novelists such as Tolstoy, Pushkin, and Lermontov did not discover the Caucasus-they produced it. ${ }^{64}$ So compelling was the literary world created by these writers that their accounts of mountains and mountaineers emerged as authoritative information on the "real" mountain landscape. For instance, Pushkin's self-described "true, if barely etched, representation of the Caucasus" was consumed by readers looking 
for factual information about the region. ${ }^{65}$ The significance of the dominance of such a literary landscape in the imagination of travelers, administrators, and later generations of writers and filmmakers is that it was a Romantic spacetime. Within such a spacetime the Caucasus were not just mountains but a sublime and transcendental landscape, and its inhabitants were not modern nineteenth-century people but medieval heroes, villains, and tragic maidens. As a result, the various populations of the Caucasus were captured in a Romantic time-out-of-time, contained like Gog and Magog behind mountain walls of literary imagination.

The Treaty of Turkmenchay in 1828 facilitated European travel into Armenia in many ways, and the following decades of weakening Persian power saw a number of Europeans crossing through the Caucasus in the name of science, diplomacy, or (in the case of the novelist Alexandre Dumas) Romantic curiosity. ${ }^{66}$ What emerges from the writings of Frederich Parrot (who crossed from Russia to scale Ararat), or Sir Robert Ker Porter and Sir Austen Henry Layard (both British antiquarians and diplomats) is an Orientalist tension between a fierce appreciation of Armenia as the land of Ararat, a heroically historic landscape, and a resolute emphasis that the dignity and heroism of that landscape be in fact situated in the past. ${ }^{67}$ What is particular about nineteenth-century natural history and antiquarianism is the way that encounters with ruins were used to produce total histories that were then linked to political and specifically imperial projects, and also the way that these moments of encounter generated ideas about the self. Specifically, the transcendental experience of standing in landscape, looking at ruins, and reflecting on the passage of time and of the mortality of human endeavors is tightly bound to modern ideas of what makes a cosmopolitan subject. Of course, this process of regard and reflection works exceptionally well if ruins of past societies are visually or narratively juxtaposed with the humble lives of contemporary ones, yielding an allegory of savage decadence held up as a mirror to modern Enlightenment. ${ }^{68}$

This period is also of critical importance for the territory of the modern Republic of Armenia, which gets drawn into historical and imperial geographies which claim stakes not only on the past but on modernity. The narrative of the Silk Road itself-remember that the term was coined in the latter half of the nineteenth century - was part of a historical project of understanding the role of Eurasian landscapes in the construction of trade economies and flourishing city-states; the travelers' tales of the medieval period acquired new currency, new "reality," as early accounts of territories where modern nations sought to build their empires. The translations and new editions I used in the writing of this chapter were themselves produced in many cases by the Hakluyt Society, a group of scientists and military officers based in Great Britain. Many of the Hakluyt Society, having served in the West Indies and under Crown rule in India, shared the conviction that historical primary sources were crucial for nineteenth century British geopolitical knowledge of and control over the Eurasian world. ${ }^{69}$ 
The reliance of imperial travelers on medieval and ancient accounts didn't merely consist of translation and research of those older sources. Part of the praxis of a learned traveler was to carry books for on-the-spot consultation; this practice had the secondary effect of submerging travelers and those they encountered into a timeless imagined landscape that, as we have traced, was inherited from the classical and medieval periods. ${ }^{70}$ Reading their accounts, it is hard not to imagine that travelers like Robert Ker Porter and Sir Austen Henry Layard rode through the Caucasus with one finger marking the page in a worn copy of the Anabasis. Passing from Erzerum to Mosul, Layard remarked on the subterranean houses of the Armenians merely that "the villages are still such as they were when Xenophon traversed Armenia." ${ }^{\prime 1}$ In a similar mode, upon entering the Caucasus from Georgia, Ker Porter allows himself a moment of pure romance: "With the advance of night succeeded a severe but brilliant frost; and the romantic scenery, with which we were surrounded, only became more animated by the change. Numerous fires appeared at various distances, under the shelter of trees, or beneath hanging shelters of rock. Around these, were seen groups of Cossacks, mingled with Georgians and Mountaineers, whose rude athletic figures, marked countenances and savage military garbs, formed pictures of the wildest character." ${ }^{2}$ This scene clearly evokes Xenophon's description of the Ten Thousand's entry into the Caucasus, and casts Ker Porter himself in the role of the courageous soldier on a mountain campaign. Note how he describes the mountain natives: rude, athletic, savage, military. By thus evoking a dark and stony land of noble savages living in a state of wild nature, Ker Porter reveals himself to be traveling through the literary adventure-scape not only of Xenophon, but also of Herodotus, Alexander, Mandeville, and of course, of imperial Russian Romanticism.

Nearly a century after Layard's journey, the novelist and historian Vassily Grossman wrote his own account of entering Armenia from the north, though this time by train. The trip itself was a liminal journey: Grossman had recently been designated a "nonperson" due to Soviet rejection of his writings, and he was in failing health that would lead to his death a few years later. Though Grossman is a richly unreliable, resolutely postmodern narrator, his description of his first glimpse of Armenian landscapes is clearly situated in literary landscapes with a long pedigree: "A mountain had died, its skeleton had been scattered on the ground. . . The houses seem not to have been built by human hands. Sometimes a gray stone comes to life and begins to move. A sheep. The sheep too must have been born from stone; probably they eat powdered stone and drink the dust of stone. . . the men are like the stones they live among." ${ }^{33}$ This description is striking, both in its effective conveyance of the alienation and discomfort of the traveler, as well in its reducing the Armenians to part of a timeless, antagonistic, stony natural landscape. Yet Grossman's account of Armenia does not rest here, in the space of (mis)adventure; the core of the novel sits in moments where the alien Grossman is 
welcomed and fed by his Armenian hosts. Ultimately, his exile has eliminated the potential of return, on which cosmopolitan transcendence supposedly depends. The author himself is the stranger dependent on tolerant locals who let him into their world.

I end this chapter with these descriptions from early modern and modern travelers to make a point, not about the chauvinism of Europeans or Soviet Russian intellectuals traveling in Armenia, but about the power of literary landscapes and chronotopes to continue to shape our perceptions of place, and of people in places. Even the brief review of more than a thousand years of writing about travel in Armenia that I have just provided shows a breadth of reasons for traveling (missionary work, pleasure, mercantile gain, military conquest), as well as different subject positions vis-à-vis the people these travelers encountered on the road. In pulling apart these differences and similarities, my goal is not to reveal the "real" Armenia that was accurately or inaccurately described by progressively more scientific travelers. If anything, the persisting literary romance that still runs through the descriptions of Ker Porter and Layard effectively demonstrates that modern "scientific" travelers were just as inclined to wonder and allegory as the medieval travelers they followed. But I do want to call attention to the evocation of Armenians as, at best, noble primitives, and at worst, subhuman stone-people, in these travel accounts that are, almost exclusively, adventure stories with male protagonists.

The persistence of the literary landscape of male adventure and transcendent encounter with strange local Others within these texts, over time, is as significant as the wealth of information that each of these accounts provided about the world at their time of writing. But we must foreground the literariness of each of these sources, and their indebtedness to old and often medieval ideas about what the East is and who and what is found there. This foregrounding reveals a bias in writing about the Silk Road that is part of the Orientalist tradition of "the West's imagination of the East," but which also extends beyond the prejudices of any single traveler or writer. The persistence of the Silk Road as a written world demonstrates the hold of medieval imagined worlds upon the present, to the extent that they shape our perceptions of the past and the people who lived there. Exceptions to this casting of medieval Armenians as nameless roadside hosts are the princes like Šahnšah and Zacharias who have names, and who make it into the histories of western travelers like Het'um and William of Rubruck. These named Armenians are yet more indelible because of the texts they themselves produced. In the next chapter, I shall scale down and look at Armenia on its own terms through the spaces produced by these texts-though I explore them in resolutely material ways. 